\title{
Monitoring fire-fighters' smoke exposure and related health effects during Gestosa experimental fires
}

\author{
A. I. Miranda ${ }^{1}$, V. Martins ${ }^{1}$, P. Cascão ${ }^{1}$, J. H. Amorim $^{1}$, J. Valente ${ }^{1}$, \\ R. Tavares ${ }^{1}, \mathrm{O}_{\text {. Tchepel }}{ }^{1}, \mathrm{C}$. Borrego ${ }^{1}, \mathrm{C}$. R. Cordeiro ${ }^{2}$, \\ A. J. Ferreira ${ }^{2}$, D. X. Viegas ${ }^{3}$, L. M. Ribeiro ${ }^{3}$ \& L. P. Pita ${ }^{3}$ \\ ${ }^{1}$ CESAM \& Department of Environment and Planning, \\ University of Aveiro, Portugal \\ ${ }^{2}$ Centre of Pulmonology of Coimbra University Medical School, Portugal \\ ${ }^{3}$ Association for the Development of Industrial Aerodynamics, \\ University of Coimbra, Portugal
}

\begin{abstract}
The main objective of this study is to contribute to the scientific knowledge regarding fire-fighters' exposure to smoke and its related health effects. Forest fire experiments were developed with an extensive number of measurements of individual exposure to smoke pollutants and of medical parameters for a group of fire-fighters. For the smoke exposure monitoring, ten fire-fighters from four different fire brigades were selected. The fire-fighters' individual exposure to toxic gases and particulate matter was monitored with portable devices, and their location in time was registered with GPS equipment. For all the monitored fire-fighters, air pollutant concentration values acquired during the fire experiments were beyond the limits recommended by the World Health Organization (WHO), namely for PM2.5, $\mathrm{CO}$ and $\mathrm{NO}_{2}$. Daily averages of PM2.5 concentration values as high as $738 \mu \mathrm{g} \cdot \mathrm{m}^{-3}$ were obtained, well above the recommended limit of $25 \mu \mathrm{g} . \mathrm{m}^{-3}$. In terms of $\mathrm{CO}$, hourly averaged values higher than $73,000 \mu \mathrm{g} \cdot \mathrm{m}^{-3}$ were monitored, clearly above the $30,000 \mu \mathrm{g} \cdot \mathrm{m}^{-3}$ recommended by the WHO. The highest $\mathrm{NO}_{2}$ hourly averaged measured value was $4,571 \mu \mathrm{g} \cdot \mathrm{m}^{-3}$, once again much higher than the recommended value of $200 \mu \mathrm{g} . \mathrm{m}^{-3}$. For VOCs, a maximum hourly average of $10,342 \mu \mathrm{g} \cdot \mathrm{m}^{-3}$ was registered for one of the fire-fighters; however, due to the lack of recommended
\end{abstract}


or legislated values it is not possible to establish a comparison. The medical tests conducted on the fire-fighters, before and after the exposure to smoke, also indicate a considerable effect on the measured medical parameters, in particular an expressive increase of $\mathrm{CO}$ concentration and a decrease of NO concentration in the exhaled air of the majority of the fire-fighters.

Keywords: smoke exposure, fire experiments, carbon monoxide, particulate matter, nitrogen dioxide, medical tests.

\section{Introduction}

Nowadays there is a growing awareness that smoke produced during forest fires can expose individuals and populations to hazardous concentrations of air pollutants. However, the current state of knowledge about the potential health impacts on fire-fighting personnel is still scarce, in particular within the European context. The most extensive measurements of smoke exposure among wild land fire-fighters were conducted in the United States of America (USA) and Australia [1-5]. From these field studies it was possible to conclude that fire-fighters can be exposed to significant levels of carbon monoxide $(\mathrm{CO})$ and respiratory irritants, including formaldehyde, acrolein, and respirable particles $[3,5]$. As a result, adverse health effects occur with acute, instantaneous eye and respiratory irritation and shortness of breath, developing into headaches, dizziness and nausea enduring for up to several hours. Additionally, long-term health effects, such as impaired respiratory function or increased risk of cancer, may be caused by these pollutants. Special concern is raised by exposure to respirable particles and potentially toxic compounds adsorbed to them (e.g. polycyclic aromatic hydrocarbons (PAHs) and semivolatile organic compounds, some of which may be carcinogenic), as well as to aldehydes, compounds that are known as probable human carcinogens. There are a number of factors that affect the impacts of smoke on health, including the concentration of air pollutants within the breathing zone of the fire-fighter, the exposure duration, exertion levels, and individual susceptibility, such as pre-existing lung or heart diseases [6].

In Europe, where an average annual value of 500,000 hectares of forest was consumed by fire in the last 29 years [7], there is a considerable lack of data on personal smoke exposure. These data are of vital importance for the establishment of cause/effect relationships between the exposure to air pollutants from smoke and fire-fighters' health effects.

Exposure results from the experiments in the USA and Australia may not be applicable to European wild land fire-fighters due to differences in vegetation, fire conditions and fire-fighting operations. The composition of smoke depends on the type of vegetation being burned, fuel moisture content, temperature of the fire and wind conditions [6]. Additionally, a major factor influencing exposure is the type of work activities that the fire-fighters carry out. Therefore it is crucial to assess exposure at the individual level and within the European context to determine whether exposure could result in health damage and what primary factors influence exposure. 
The main purpose of this paper is to contribute to the fire-fighters' smoke exposure and related health effects knowledge. The current work presents and analyzes the data on individual exposure to $\mathrm{CO}$, nitrogen dioxide $\left(\mathrm{NO}_{2}\right)$, volatile organic compounds (VOCs), and particles with an aerodynamic diameter lesser than $2.5 \mu \mathrm{m}$ (PM2.5), which were obtained during field burning experiments for a group of ten fire-fighters equipped with portable "in continuum" measuring devices. A group of 14 fire-fighters were also tested before and after fire-fighting regarding their exhaled nitric oxide $(\mathrm{eNO})$ and $\mathrm{CO}$.

\section{Methodology and equipment}

The measurement of fire-fighters individual exposure and of the medical parameters was conducted during the Gestosa 2008 and 2009 fire experiments, in Central Portugal, at the end of spring season.

\subsection{Study area characteristics}

The study area is located in the mountain range of Lousã, Central Portugal, at an altitude between 900 and $1,100 \mathrm{~m}$. The vegetation was mainly composed by continuous shrubs of three dominant species: Erica umbellata, Ulex minor and Chamaespartium tridentatum. In Figure 1 it is possible to have a perspective of the study area general characteristics, for 2008 and 2009 fire experiments.

The study areas were divided into 7 and 4 plots in 2008 and 2009, respectively, with regular shapes and variable dimensions. For 2008 plots varied between 874 and $2,820 \mathrm{~m}^{2}$ and for 2009 plots varied between 1,800 and $6,057 \mathrm{~m}^{2}$. These experimental burning plots were established within Forest Service lands, and within the Gestosa forestry perimeter.

Before the experiments the burning plots were prepared and the vegetation properties analysed. The characteristics of the experimental plots and available fuel are presented in Table 1.

During one month before the experiments, hourly data related with wind speed, wind direction, precipitation, air temperature and relative humidity were
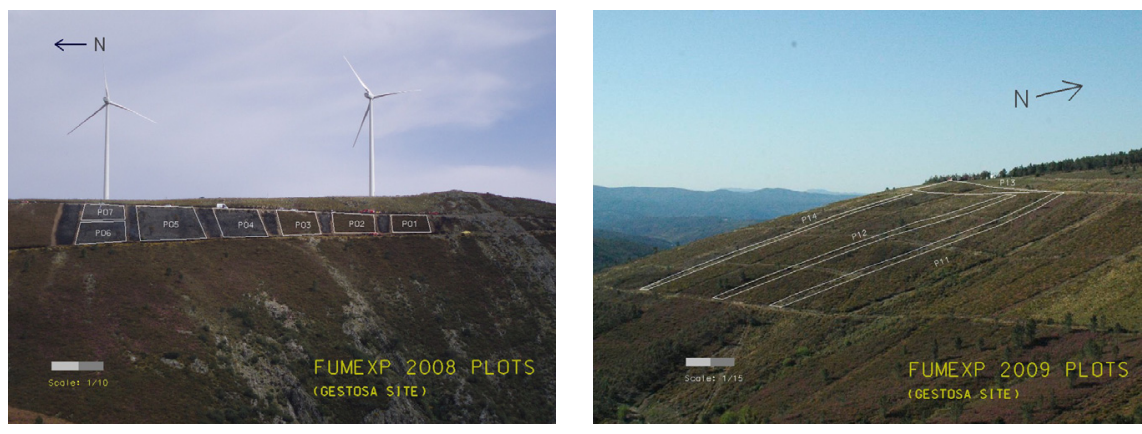

Figure 1: Plot layouts from the Gestosa 2008 and Gestosa 2009 study areas. 
Table 1: $\quad$ Main characteristics of the experimental plots (Gestosa 2008 and 2009).

\begin{tabular}{|l|c|c|c|c|c|c|}
\hline Plot & $\begin{array}{c}\text { Area } \\
\left(\mathrm{m}^{2}\right)\end{array}$ & $\begin{array}{c}\text { Slope } \\
\left({ }^{\circ}\right)\end{array}$ & $\begin{array}{c}\text { Fuel cover } \\
(\%)\end{array}$ & $\begin{array}{c}\text { Fuel height } \\
(\mathrm{cm})\end{array}$ & $\begin{array}{c}\text { Fuel bulk density } \\
(\mathrm{kg.m})\end{array}$ & $\begin{array}{c}\text { Fuel load } \\
\left(\text { ton.h }^{-1}\right)\end{array}$ \\
\hline \multicolumn{7}{|l|}{ Gestosa 2008} \\
\hline P01 & 820 & 20 & 100.00 & 83.25 & 2.04 & 24.79 \\
\hline P02 & 959 & 27 & 100.00 & 93.00 & 2.06 & 26.69 \\
\hline P03 & 1,228 & 24 & 98.20 & 85.95 & 2.11 & 26.31 \\
\hline P04 & 1,493 & 22 & 86.00 & 70.40 & 2.26 & 22.41 \\
\hline P05 & 2,642 & 20 & 100.00 & 66.53 & 2.23 & 33.58 \\
\hline P06 & 1,089 & 23 & 100.00 & 83.00 & 2.28 & 31.17 \\
\hline P07 & 1,049 & 17 & 100.00 & 66.25 & 2.34 & 29.15 \\
\hline Gestosa 2009 & & & & $*$ \\
\hline P11 & 2,552 & 19 & $*$ & $*$ & $*$ & $*$ \\
\hline P12 & 1,800 & 17 & $*$ & $*$ & $*$ & $*$ \\
\hline P13 & 6,057 & 14 & $*$ & $*$ & $*$ & $*$ \\
\hline P14 & 2,990 & 19 & $*$ & $*$ & $*$ & $*$ \\
\hline
\end{tabular}

* Plots are safety areas with little vegetation.

recorded by a Geolog $\mathrm{S}$ meteorological station. This information allowed assessing the best period of the day to burn with the advisable wind conditions.

The duration of the burns in Gestosa 2008 was rather small (10-15 minutes) when compared to wildfires. Although the fire duration during Gestosa 2009, which lasted for almost one hour for a specific plot, is higher than during Gestosa 2008, the plots had little vegetation and that limited the fire-fighter's exposure to smoke.

\subsection{Smoke exposure}

For the smoke exposure monitoring, 10 fire-fighters were selected from four different fire corporations. Fire-fighters were chosen based on predefined criteria that took into account the age, smoking habits, respiratory diseases and function in the fire brigade. The selected fire-fighters were equipped with sampling devices monitoring individual exposure to $\mathrm{CO}, \mathrm{VOC}, \mathrm{NO}_{2}$ and PM2.5. Moreover, the location of each corporation in time was registered with GPS equipment. For the selection of the monitoring equipment some important aspects were considered, namely their weight and the robustness, as well as the measuring ranges. Figure 2 shows some fire-fighters with the exposure monitoring equipment.

VOC and $\mathrm{NO}_{2}$ were monitored continuously using integrated photo-ionization detector GasAlertMicro 5 PID from BW Technologies. The rechargeable battery allows a continuous operation up to 12 hours and with the memory card is capable of recording two months of data. The VOC and $\mathrm{NO}_{2}$ sensors were calibrated before the burn using a $100 \mathrm{ppm}$ isobutylene and $10 \mathrm{ppm} \mathrm{NO}_{2}$ calibration gas, respectively. 


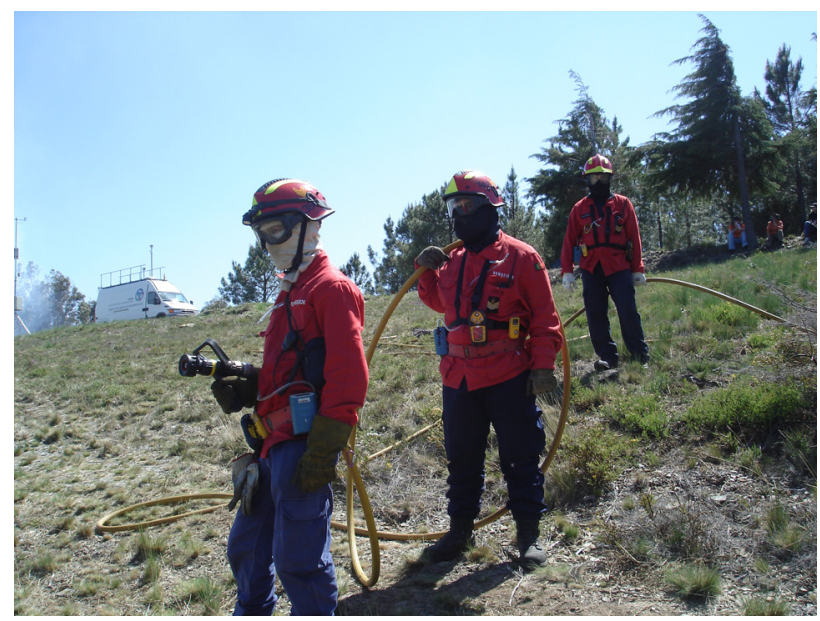

Figure 2: $\quad$ Fire-fighters with the exposure monitoring equipment.

Table 2: Characteristics of the equipment.

\begin{tabular}{|c|c|c|c|c|}
\hline \multirow{2}{*}{ Pollutant } & \multirow{2}{*}{ Type of data } & \multirow{2}{*}{ Equipment } & \multicolumn{2}{|c|}{ Characteristics } \\
\hline & & & Range & Resolution \\
\hline VOC & \multirow{2}{*}{$\begin{array}{c}\text { Continuous } \\
\text { measurement: } \\
5 \text { seconds interval }\end{array}$} & \multirow{2}{*}{$\begin{array}{l}\text { GasAlertMicro } 5 \text { PID } \\
\text { from BW Technologies }\end{array}$} & $0-1,000 \mathrm{ppm}$ & $1 \mathrm{ppm}$ \\
\hline $\mathrm{NO}_{2}$ & & & 0-99.9 ppm & $0.1 \mathrm{ppm}$ \\
\hline \multirow{2}{*}{$\mathrm{CO}$} & \multirow{2}{*}{$\begin{array}{c}\text { Continuous } \\
\text { measurement: } \\
5 \text { seconds interval }\end{array}$} & $\begin{array}{l}\text { GasAlertMicroClip from } \\
\text { BW Technologies }\end{array}$ & $0-500 \mathrm{ppm}$ & $1 \mathrm{ppm}$ \\
\hline & & $\begin{array}{l}\text { GasAlertextreme from } \\
\text { BW Technologies }\end{array}$ & $0-1,000 \mathrm{ppm}$ & $1 \mathrm{ppm}$ \\
\hline PM2.5 & $\begin{array}{c}\text { Continuous } \\
\text { measurement: } \\
1 \text { minute interval }\end{array}$ & $\begin{array}{c}\text { Personal Aerosol Monitor } \\
\text { SidePack AM510 from } \\
\text { TSI }\end{array}$ & $0-20 \mathrm{mg} \cdot \mathrm{m}^{-3}$ & $0.001 \mathrm{mg} \cdot \mathrm{m}^{-3}$ \\
\hline
\end{tabular}

$\mathrm{CO}$ was also monitored continuously using a CO GasAlertMicroClip and CO GasAlertextreme from BW Technologies, in Gestosa 2008 and 2009, respectively. The $\mathrm{CO}$ detector was calibrated before the fire experiments using a 100 ppm CO calibration gas.

PM2.5 monitoring was performed using the monitor SidePack AM510 Personal Aerosol Monitor from TSI Inc. fitted with a built in $2.5 \mu \mathrm{m}$ cut off impactor at a constant flow rate of $1.7 \mathrm{~L} \cdot \mathrm{min}^{-1}$. Before the fire experiments the flow rate was calibrated and the monitor was zeroed using a zero filter. Table 2 summarizes the characteristics of the equipments. 


\subsection{Air quality limit values}

Aiming to better understand the effects of these experimental fires on the firefighters health, the measured results were compared to the European air quality legislation values and to the values recommended by the WHO (Table 3).

Both the air quality legislation limit values as well as the WHO standards were established aiming to protect the human health from the air pollution effects. In general, the proposed limit values agree with only one exception regarding PM2.5, for which $\mathrm{WHO}$ is more demanding. Moreover, the WHO recommends limit values for other time periods than those considered by the European Directive.

\subsection{Medical tests}

The respiratory function of a 38 fire-fighters sample was evaluated, prior to any exposure, during April 2008. They also answered the SF-36 questionnaire, which regards the general quality of health. An initial subgroup of 14 non smoker firefighters was tested during 2008, before and after fire-fighting, regarding to their eNO and CO. During the Gestosa 2009 experiments, eNO, CO and \% carboxyhaemoglobin $(\mathrm{COHb})$ were also registered for a similar sub-group of 14 firefighters, pre and post smoke exposure. In 2009, a sample of exhaled breath condensate was collected too, before and after smoke exposure, for the determination of lung inflammatory patterns. Table 4 summarizes the characteristics of the medical equipments.

Table 3: Air quality limit values for the protection of human health established by European legislation and recommended by the WHO.

\begin{tabular}{|c|c|c|}
\hline Pollutant & $\begin{array}{c}\text { European Legislation } \\
(2008 / 50 / \mathrm{CE})\end{array}$ & WHO \\
\hline \multirow{2}{*}{ PM2.5 } & \multirow{2}{*}{$25 \mu \mathrm{g} \cdot \mathrm{m}^{-3}$ (1 year) } & $25 \mu \mathrm{g} \cdot \mathrm{m}^{-3}$ (24 hour) \\
\hline & & $10 \mu \mathrm{g} \cdot \mathrm{m}^{-3}$ (1 year) \\
\hline \multirow{2}{*}{$\mathrm{NO}_{2}$} & $200 \mu \mathrm{g} \cdot \mathrm{m}^{-3}$ (1 hour) & $200 \mu \mathrm{g} \cdot \mathrm{m}^{-3}$ (1 hour) \\
\hline & $40 \mu \mathrm{g} \cdot \mathrm{m}^{-3}$ (1 year) & $40 \mu \mathrm{g} \cdot \mathrm{m}^{-3}$ (1 year) \\
\hline \multirow{4}{*}{$\mathrm{CO}$} & \multirow{4}{*}{$10 \mathrm{mg} \cdot \mathrm{m}^{-3}$ (8 hours) } & 100 mg.m ${ }^{-3}$ (15 minutes) \\
\hline & & $60 \mathrm{mg} \cdot \mathrm{m}^{-3}$ (30 minutes) \\
\hline & & $30 \mathrm{mg} \cdot \mathrm{m}^{-3}$ (1 hour) \\
\hline & & $10 \mathrm{mg} \cdot \mathrm{m}^{-3}$ (8 hours) \\
\hline
\end{tabular}

Table 4: $\quad$ Characteristics of the medical equipment.

\begin{tabular}{|c|c|c|c|}
\hline \multirow{2}{*}{ Parameter } & Equipment & \multicolumn{2}{|c|}{ Characteristics } \\
\cline { 3 - 4 } & eNO & Range & Resolution \\
\hline Alveolar CO & $\begin{array}{c}\text { MICRO CO/Smoke-check from } \\
\text { Micromedical }\end{array}$ & $5-300 \mathrm{ppb}$ & $1 \mathrm{ppb}$ \\
\hline
\end{tabular}




\section{Results and discussion}

\subsection{Smoke exposure}

To assess fire-fighters exposure to smoke pollutants and taking into account the recommended limit values (see Table 3), 1 hour averages for $\mathrm{CO}, \mathrm{VOC}$ and $\mathrm{NO}_{2}$ and 24 hours averages for PM2.5 were calculated for every monitored firefighter. Table 5 presents the maximum hourly-averaged values for $\mathrm{CO}, \mathrm{NO}_{2}$ and VOC and the daily averages for PM2.5. This last one was calculated considering zero PM2.5 values for the non-exposure time periods.

For all the monitored fire-fighters, a considerable number of the air pollutants concentration values acquired during their activity is beyond the limits recommended by the WHO (see bold values in Table 5), namely for PM2.5, CO

Table 5: Highest hourly averages of $\mathrm{CO}, \mathrm{NO}_{2}$ and $\mathrm{VOC}$ and 24 hour averages for PM2.5.

\begin{tabular}{|c|c|c|c|c|}
\hline \multirow{2}{*}{ Fire-fighter } & $\mathrm{CO}$ & $\mathrm{NO}_{2}$ & VOC & \multirow{2}{*}{$\frac{\text { PM2.5 }}{\left(\mu \mathrm{g} \cdot \mathrm{m}^{-3} \cdot \text { day }^{-1}\right)}$} \\
\hline & \multicolumn{3}{|c|}{$\left(\mu \mathrm{g} \cdot \mathrm{m}^{-3} \cdot \mathrm{h}^{-1}\right)$} & \\
\hline \multicolumn{5}{|c|}{ Gestosa 2008} \\
\hline 1 & 32,479 & 2,163 & 1,585 & 260 \\
\hline 2 & 73,033 & 4,172 & 3,934 & 184 \\
\hline 3 & 47,223 & 3,641 & 415 & 306 \\
\hline 4 & 50,881 & 274 & 1,789 & 240 \\
\hline 5 & 33,178 & 709 & 599 & 738 \\
\hline 6 & 49,078 & n.d. & 2,917 & 735 \\
\hline 7 & n.d. & 2,599 & 1,838 & 684 \\
\hline 8 & $\mathbf{3 5 , 8 4 7}$ & 609 & 1,520 & 479 \\
\hline 9 & 48,259 & 4,571 & 5,302 & 610 \\
\hline 10 & n.d. & 82 & 2,097 & 206 \\
\hline \multicolumn{5}{|c|}{ Gestosa 2009} \\
\hline 1 & 12,586 & 344 & 54 & 44 \\
\hline 2 & 22,814 & 332 & 526 & 400 \\
\hline 3 & 32,222 & 485 & 496 & 124 \\
\hline 4 & 39,090 & 142 & 343 & 315 \\
\hline 5 & 36,199 & 884 & 337 & 152 \\
\hline 6 & 30,669 & 1,544 & 10,342 & 40 \\
\hline 7 & 4,903 & 132 & 62 & 66 \\
\hline 8 & 41,9389 & 788 & 1,377 & 396 \\
\hline 9 & 42,023 & 802 & 376 & 176 \\
\hline 10 & 17,899 & 1,091 & 1,076 & 358 \\
\hline
\end{tabular}

n.d. - No data 
and $\mathrm{NO}_{2}$. Daily averages of PM2.5 concentration values as high as $738 \mu \mathrm{g} . \mathrm{m}^{-3}$ were obtained, well above the recommended limit of $25 \mu \mathrm{g} \cdot \mathrm{m}^{-3}$, even considering that during the rest of the day the concentration was $0 \mu \mathrm{g} . \mathrm{m}^{-3}$. In terms of $\mathrm{CO}$, hourly averaged values higher than $73,000 \mu \mathrm{g} \cdot \mathrm{m}^{-3}$ were monitored, clearly above the $30,000 \mu \mathrm{g} \cdot \mathrm{m}^{-3}$ recommended by the WHO. The highest $\mathrm{NO}_{2}$ hourly averaged measured value was $4,571 \mu \mathrm{g} \cdot \mathrm{m}^{-3}$, once again much higher than the recommended value of $200 \mu \mathrm{g} \cdot \mathrm{m}^{-3}$. For VOC, a maximum hourly average of $10,342 \mu \mathrm{g} \cdot \mathrm{m}^{-3}$ was registered for one of the fire-fighters; however, due to the lack of recommended or legislated values for total VOC it is not possible to establish a comparison.

Aiming to have the time evolution of exposure values along the experiments, hourly averaged values for the measured pollutants during Gestosa 2008 and Gestosa 2009, for two particular fire-fighters, are presented in Figure 3.

The hourly averages for the pollutants show a similar pattern in terms of concentration variation, which is related to the smoke exposure. PM2.5 and CO are the pollutants that present the highest concentrations.
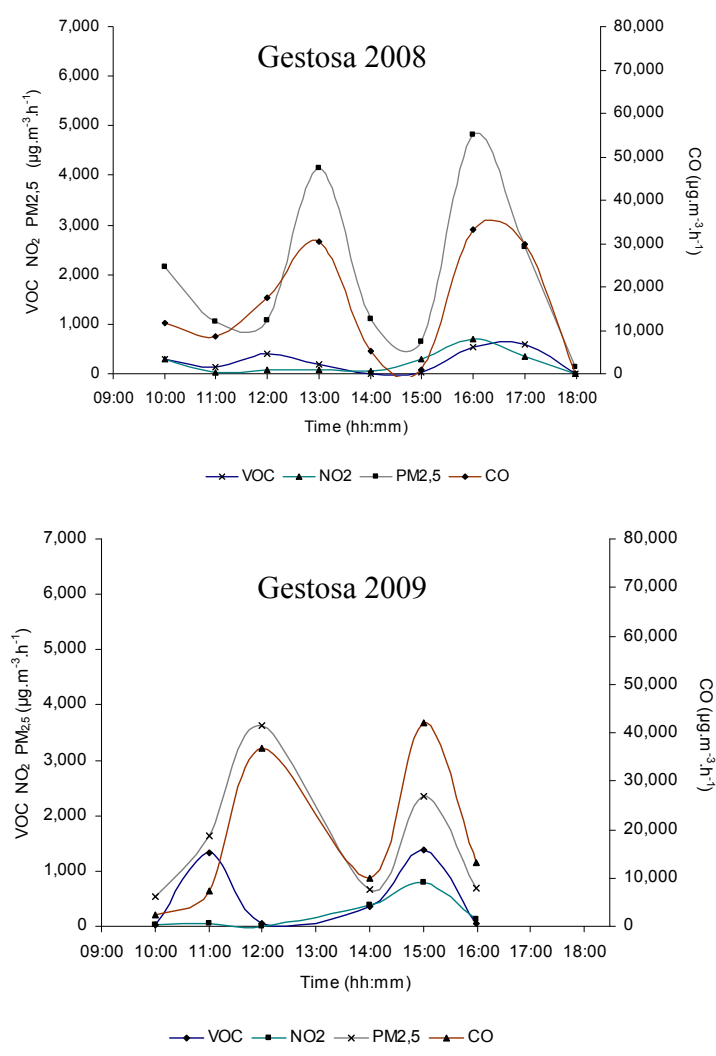

Figure 3: Hourly averaged exposure values in Gestosa 2008 and 2009 for fire-fighters 5 and 8 . 

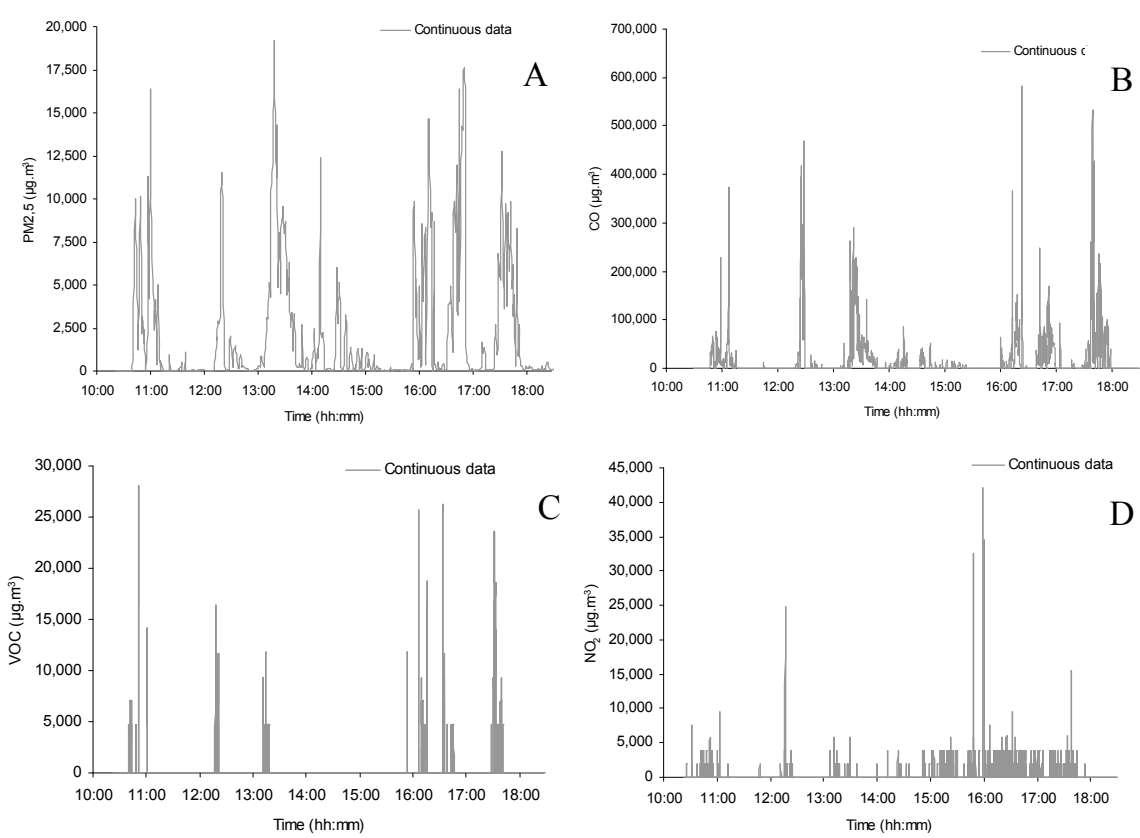

Figure 4: $\mathrm{PM}$ 2.5, $\mathrm{CO}, \mathrm{VOC}$ and $\mathrm{NO}_{2}$ concentrations measured during Gestosa 2008 for fire-fighter 5 (A, B, C and D respectively).

Figure 4 also shows the instantaneous registered data along the Gestosa 2008 experiments, for the fire-fighter 5 .

The instantaneous CO concentration values acquired during the Gestosa 2008 were very high, reaching a maximum value above $600,000 \mu \mathrm{g} . \mathrm{m}^{-3}$. PM2.5 values were also very high $\left(19,953 \mu \mathrm{g} \cdot \mathrm{m}^{-3}\right)$. These data show the magnitude of the exposure peaks occurred during regular fire-fighting operations. For instance, the knowledge of the $\mathrm{CO}$ concentration peaks to which fire-fighters are exposed is quite important, since high concentrations of this gas can cause death by asphyxia. The same type of results was obtained for Gestosa 2009.

\subsection{Health assessment}

Figures 5 and 6 illustrate the changes in the medical measured parameters in Gestosa 2008 and 2009, respectively.

The medical tests conducted on the fire-fighters in 2008, before and after the exposure to smoke, indicate a considerable effect on the measured parameters. Regarding CO concentration in the exhaled air: (i) there was a higher number of fire-fighters with concentration values above $7 \mathrm{ppm}$ after fire $(20 \mathrm{ppm}$ were even registered for one fire-fighter); (ii) before fire 11 fire-fighters had $\mathrm{CO}$ levels in the [0-6] ppm range, and after fire only 2 remained in the same interval. 
92 Modelling, Monitoring and Management of Forest Fires II
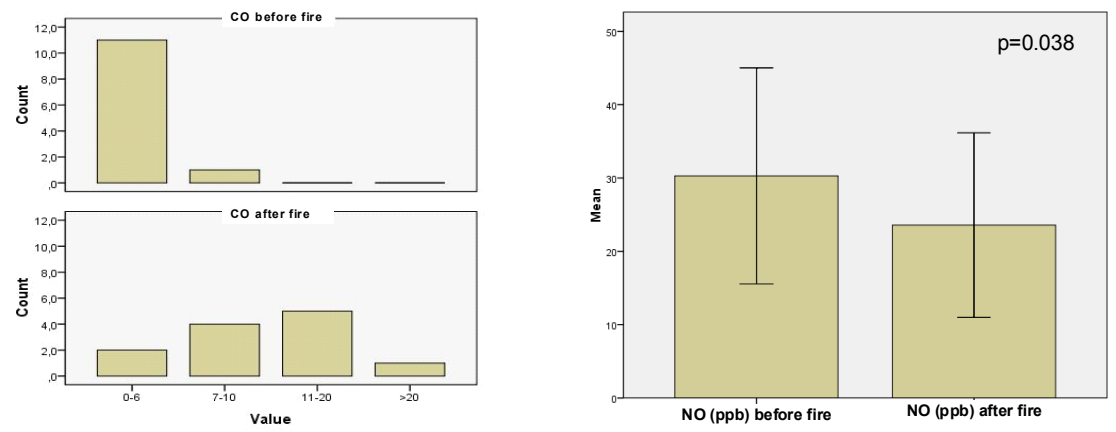

Figure 5: Medical test results for Gestosa 2008 before and after fire exposure, for $\mathrm{CO}(\mathrm{ppm})$ and $\mathrm{NO}(\mathrm{ppb})$.
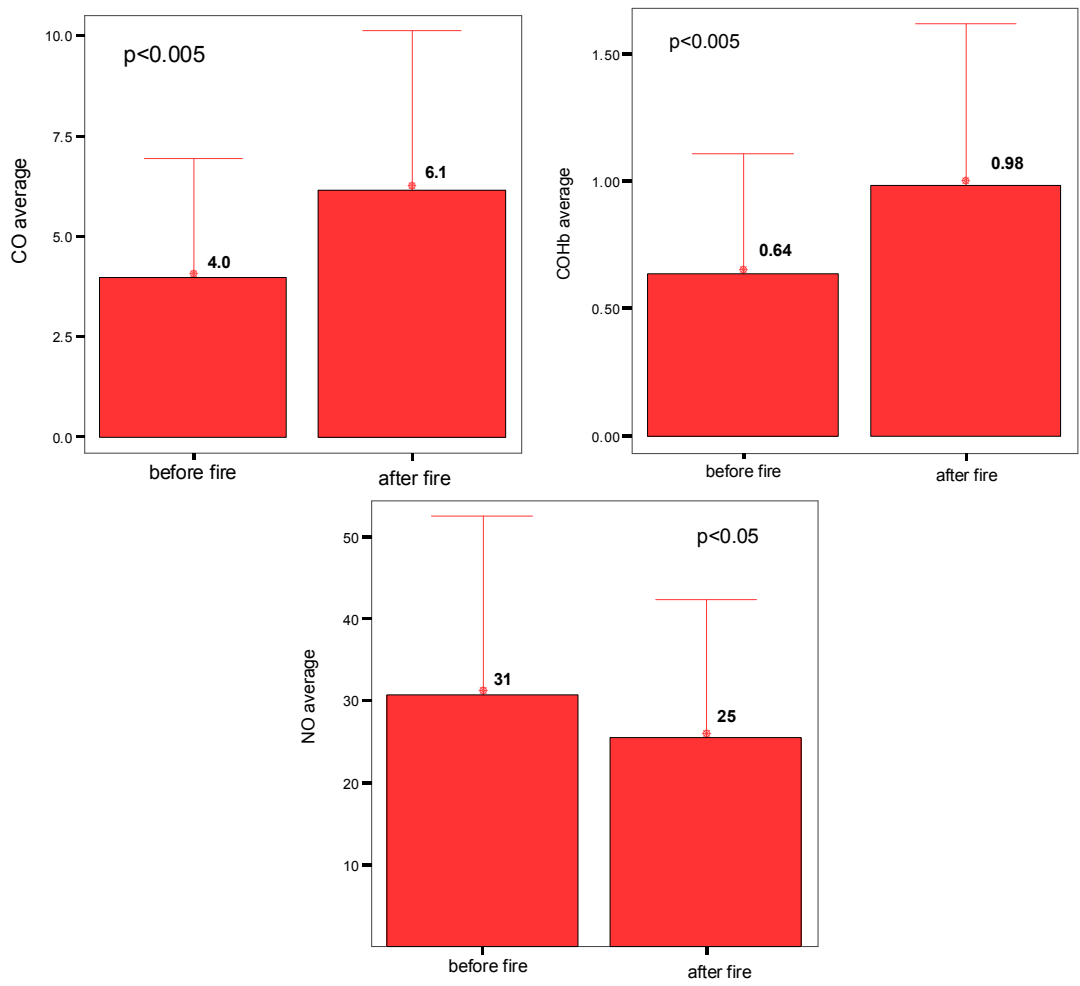

Figure 6: Medical tests results for Gestosa 2009 before and after fire exposure ( $\mathrm{CO}$ and $\mathrm{COHb}$ in $\mathrm{ppm}, \mathrm{NO}$ in $\mathrm{ppb})$. 
In what concerns the exhaled NO, there was a significant decrease $(\mathrm{p}=0.038)$ between the values measured before and after the exposure to smoke, achieving $5 \mathrm{ppb}$. This could indicate an effect similar to the exposure to cigarette smoke. Indeed, in current smokers, it is usually observed a decrease on exhaled nitric oxide, probably related to the inhibition of nitric oxide synthetase [8].

Figure 6 shows, for $\mathrm{CO}, \mathrm{COHb}$ and $\mathrm{NO}$, the averaged values for the 14 monitored fire-fighters. In the scope of the previously observed, there was a strong increase $(\mathrm{p}<0.005)$ of the exhaled $\mathrm{CO}$ and $\mathrm{COHb}$ after fire, reaching 2.10 ppm and $0.34 \mathrm{ppm}$, respectively. In terms of NO in the exhaled air, there was a decrease $(p<0.05)$ in the order of $6 \mathrm{ppb}$.

\section{Conclusions}

Usually, the amount and characteristics of noxious exposure of forest firefighters are not widely recognized; more attention has been drawn upon the risks of indoor fire-fighting. Our work indicates that forest fire-fighting can expose individuals to very high concentrations of $\mathrm{CO}, \mathrm{VOC}, \mathrm{NO}_{2}$ and $\mathrm{PM} 2.5$, with potential harmful effects on human health. Urgent measures to avoid these levels of exposure are needed. They can be related to the use of adequate protecting devices, to a correct planning of fire-fighting shifts, and/or to the operational availability of information regarding the areas of higher pollutants levels that can be obtained through modelling of exposure.

\section{Acknowledgements}

The authors would like to acknowledge the financial support of the Portuguese Ministry of Science, Technology and Higher Education, through the Foundation for Science and Technology (FCT), for the $\mathrm{PhD}$ grants of $\mathrm{V}$. Martins (SFRH/BD/39799/2007), J. Valente (SFRH/BD/22687/2005), R. Tavares (SFRH/BD/22741/2005) and the Post-Doc grant of J.H. Amorim (SFRH/BPD/48121/2008). In addition, FCT is acknowledged for the funding of the National research project FUMEXP (PTDC/AMB/66707/2006) through the POCI2010 program and the FEDER fund.

\section{References}

[1] McMahon, C.K., Bush, P.B., Forest worker exposure to airborne herbicide residues in smoke from prescribed fires in the southern United-States. $\mathrm{Am}$ Ind Hyg Assoc J 53(4), pp. 265-72, 1992.

[2] Materna, B.L., Koshland, C.P., Harrison, R.J., Carbon monoxide exposure in wildland firefighting: a comparison of monitoring methods. Appl Occup Environ Hyg, 8(5), pp.479-87, 1993.

[3] Reinhardt, T.E., Ottmar, R.D., Smoke exposure at western wildfires. USDA Forest Service Pacific Northwest Research Station Research Paper (525), 2000 . 
94 Modelling, Monitoring and Management of Forest Fires II

[4] Reinhardt, TE, Ottmar, RD, Hanneman, A., Smoke exposure among firefighters at prescribed burns in the Pacific Northwest. USDA Forest Service Pacific Northwest Research Station Research Paper (526), pp. U145, 2000.

[5] Reinhardt, T.E., Ottmar, R.D., Baseline measurements of smoke exposure among wildland firefighters, J Occup Environ Hyg 1(9), pp. 593-606, 2004.

[6] Reisen, F., Brown, S.K., Australian firefighters' exposure levels to air toxics during bushfire burn of autumn 2005 and 2006. Environment International 35, pp. 342-352, 2009.

[7] European Commission, Forest Fires in Europe 2008. EUR 23971 EN. ISSN 1018-5593, 2009.

[8] Malinovschi, A., Janson, C., Holmkvist, T., Norback, D., Merilainen, P., M. Hogman, N., Effect of smoking on exhaled nitric oxide and flow independent nitric oxide exchange parameters. Eur Respir $J$ (28), pp. 339345, 2006. 